\title{
Microplants production of Eucalyptus cloeziana from indirect organogenesis
}

\author{
Producción de microplantas de Eucalyptus cloeziana por organogénesis indirecta
}

\section{Alex Zichner Zorz a , Júlio Cézar Tannure Faria ${ }^{\text {b }}$, Denys Matheus Santana Costa Souza ${ }^{\text {b, }}$ Douglas Santos Gonçalves beandro Silva de Oliveira ${ }^{\mathrm{c}}$, André Luís Lopes Da Silva d, Wellington Ferreira Campos ${ }^{\mathrm{e}}$, Gilvano Ebling Brondani ${ }^{\mathrm{b} *}$}

\author{
${ }^{\text {a }}$ Federal University of Mato Grosso (UFMT), College of Forestry, Fernando Corrêa da Costa Avenue, 2367, \\ Cuiabá, MT, 78060-900, Brazil. \\ *Corresponding author: ${ }^{\mathrm{b}}$ Federal University of Lavras (UFLA), Department of Forestry Sciences, \\ P.O. Box 3037, 37200-900, Lavras, MG, Brazil, gebrondani@gmail.com or gilvano.brondani@ufla.br \\ ${ }^{\mathrm{c}}$ Federal University of Minas Gerais (UFMG), Institute of Agronomic Sciences, Universitária Avenue, \\ n.1000, 39404-547, Montes Claros, MG, Brazil. \\ d State University of Bahia, Department of Technology and Social Sciences, Edgar Chastinet, \\ s/n, 48905-680, Juazeiro, BA, Brazil. \\ ${ }^{\text {e }}$ Federal University of Jequitinhonha e Mucuri Valleys (UFVJM), Institute of Agronomic Sciences, \\ Vereador João Narciso Avenue, n.1380, 38610-000, Unaí, MG, Brazil.
}

\begin{abstract}
SUMMARY
Few studies have focused on the in vitro multiplication methods for Eucalyptus cloeziana. In this work we developed an indirect organogenesis protocol to obtain micropropagated plants. The interactions of plant growth regulators in juvenile tissues were evaluated. Hypocotyl, cotyledon and root tissues obtained from in vitro germinated seedlings were subjected to combinations of $\alpha$-naphthaleneacetic acid (NAA), thidiazuron (TDZ) and 2,4-dichlorophenoxyacetic acid (2,4-D). In vitro callogenesis, adventitious bud induction, shoot elongation, and ex vitro survival and rooting were evaluated. Callogenic structures were observed in all evaluated tissues. Morphogenic characteristics related to the meristematic center was observed. The tissues that presented the callus mass were subcultured in a regeneration culture medium supplemented with $1.0 \mathrm{mg} \mathrm{L}^{-1}$ of 6-benzylaminopurine (BAP). Only hypocotyl and cotyledon induced adventitious bud and shoot elongation. Hypocotyl subjected to $2.0 \mathrm{mg} \mathrm{L}^{-1} \mathrm{TDZ}$ had the highest number of elongated shoots. The two tissues (i.e., hypocotyl and cotyledon) combined with thidiazuron were characterized by the ex vitro survival of microcuttings and by adventitious rooting. Results confirmed tissue culture efficiency for microplants production by indirect organogenesis from hypocotyl and cotyledon cultivated with TDZ, and its implementation can be an alternative for forest tree breeding programs of E. cloeziana.
\end{abstract}

Key words: adventitious rooting, callogenesis, indirect regeneration, adventitious bud.

\section{RESUMEN}

Pocos estudios se han centrado en los métodos de multiplicación in vitro para Eucalyptus cloeziana. En este trabajo se desarrolló un protocolo de organogénesis indirecta para obtener plantas micropropagadas. Se evaluaron las interacciones de los reguladores del crecimiento en tejidos juveniles. Los tejidos del hipocótilo, cotiledón y raíces obtenidos de plántulas germinadas in vitro se sometieron a combinaciones de ácido $\alpha$-naftaleneacético (ANA), tidiazurón (TDZ) y ácido 2,4-diclorofenoxiacético (2,4-D). Se evaluaron la callogénesis in vitro, la inducción adventicia de yemas, el alargamiento de brotes, y la sobrevivencia y enraizamiento ex vitro. Se observaron estructuras calogénicas en todos los tejidos evaluados. Se observaron características morfogénicas relacionadas con la formación de centros meristemáticos. Los tejidos que presentaron la masa del callo fueron subcultivados en medio de cultivo de regeneración suplementado con 1,0 $\mathrm{mg} \mathrm{L}^{-1}$ de 6-bencilaminopurina (BAP), y solo los tejidos del hipocótilo y cotiledón formaron yemas adventicias y brotes alargados. Los tejidos del hipocótilo sometidos a 2,0 $\mathrm{mg} \mathrm{L}^{-1}$ de tidiazuron obtuvieron mayor número de brotes alargados. Los dos tejidos (hipocótilo y cotiledón) combinados con TDZ se caracterizaron por sobrevivencia y el enraizamiento adventicio ex vitro de las microestacas. Los resultados confirmaron la eficiencia del cultivo de tejidos para la producción de microplantas por organogénesis indirecta a partir de tejidos del hipocótilo y cotiledón cultivados con TDZ y su implementación puede ser una alternativa para los programas de mejoramiento forestal de E. cloeziana.

Palabras clave: enraizamiento adventicio, callogénesis, regeneración indirecta, brote adventicio. 


\section{INTRODUCTION}

The genera Eucalyptus and Corymbia are the most cultivated exotic species of the forest sector. They are well recognized for their silvicultural characteristics, fast growth, great ecological plasticity and wood properties, making them attractive for numerous industrial applications (Brondani et al. 2018, Arriel et al. 2019). Among these genera, several species still have been evaluated for commercial plantation establishment, because of the growing demand for forest products. Such species include Eucalyptus cloeziana F. Muell., which stands out for its wide applications, including the production of raw materials for furniture, construction, energy and pulp and paper industries, and has established itself in the industrial sector in Brazil (Alves et al. 2017).

In vitro plant regeneration techniques have been used as complementary tools to forest tree breeding, where the development of a tissue culture protocol is essential to obtain whole plants on a large scale. The phases of tissue regeneration, bud multiplication, shoot elongation and subsequent rooting and acclimatization can only be performed after the establishment of aseptic cultures with good vegetative vigor (Silva et al. 2019). One of the current methodologies adopted as an alternative to obtain complete plants is indirect organogenesis by the induction of callus, and it has several applications, such as the production of transgenic plants (Silva et al. 2019).

The use of indirect organogenesis allows the formation of adventitious bud and shoot elongation for producing large quantities of microplants in a short period and enables the study of different morphogenetic and physiological phenomena (Hesami and Daneshvar 2018), production of secondary metabolites (Mutawil et al. 2016), transgenic plants, polyploidy, and somaclonal variations (Hesami and Daneshvar 2018) and callus culture for growing cells in suspension (Silva et al. 2019).

Callogenesis and bud induction occur from the redifferentiation of the cells forming new tissue, as these processes are directly controlled by morphophysiological events that regulate endogenous mechanisms, proteins and DNA methylation (Pan et al. 2010). Thus, the influence of the incubation conditions has been studied in several Eucalyptus species (Fernando et al. 2016) during organogenesis. These changes may occur due to the composition of the culture medium, nutrition, balance between the plant growth regulators, type and ontogenetic age of the explant and determination of the tissues (Brondani et al. 2012, 2018, Oliveira et al. 2015, Mittal and Sharma 2017, Souza et al. 2019).

Eucalyptus cloeziana is important in the forest sector, therefore obtaining an efficient and reproducible protocol for indirect tissue regeneration is essential to propagate improved genotypes. Furthermore, the knowledge generated may contribute to plants production by specialized forest companies, producers of improved plants and re- search institutions in different world regions. In this context, the present study aimed at establishing an indirect organogenesis protocol for E. cloeziana from hypocotyl, cotyledon and root tissues, regarding: (i) tissue competence and plant growth regulator concentrations for the induction of callus structures; (ii) presence of meristematic center; (iii) in vitro adventitious bud induction and shoot elongation; (iv) ex vitro survival of microcuttings and adventitious rooting.

\section{METHODS}

Source of tissues. Hypocotyl, cotyledon and root tissues were collected from E. cloeziana F. Muell seedlings germinated in vitro. The seeds originated from a Seed Producing Area (SPA) in Anhembi, state of São Paulo, Brazil, from cultivar LCFA026 of the Forest Science and Research Institute (IPEF).

Seed disinfection and in vitro germination. Seeds were pre-treated by imbibition in distilled water for 24 hours. Subsequently, seeds were washed under tap water for 5 minutes and sterilized first in a $70 \%$ ethanol solution for 90 seconds and then in sodium hypochlorite $(\mathrm{NaOCl}$, 2.0-2.5\% active chlorine) containing one drop $(0.05 \mathrm{~mL})$ of tween-20 for 25 minutes. After the disinfection process, seeds were washed three times with autoclaved distilled water. The seeds selected for cultivation were those that showed a state of turgidity and white color (Oliveira et al. 2015). Seeds were in vitro inoculated in glass test tubes $(20 \times 100 \mathrm{~mm})$ containing $6 \mathrm{~mL}$ of the culture medium composed only of distilled water and agar. Seeds were kept under ambient growth room conditions until tissue was collected.

Preparation of the culture medium. The culture medium was prepared with deionized water, $6 \mathrm{~g} \mathrm{~L}^{-1}$ of agar and $30 \mathrm{~g} \mathrm{~L}^{-1}$ of sucrose. The $\mathrm{pH}$ of the medium was adjusted to 5.8 with $0.1 \mathrm{~N}-\mathrm{HCl}$ and $0.1 \mathrm{~N}-\mathrm{NaOH}$ before the agar was added, and afterwards, the mixture was autoclaved at $121{ }^{\circ} \mathrm{C}\left(\sim 1.0 \mathrm{kgf} \mathrm{cm}^{-2}\right)$ for 20 minutes. Before the culture medium was autoclaved, a plant growth regulator was added.

Culture conditions under growth room. The growth room had a temperature of $25^{\circ} \mathrm{C}\left( \pm 2{ }^{\circ} \mathrm{C}\right)$, photoperiod of 16 hours of light and irradiance from cool white fluorescent lamps of $32 \mu \mathrm{mol} \mathrm{m}{ }^{-2} \mathrm{~s}^{-1}$.

Callus culture. Seedlings obtained in vitro after 20 days of germination were used to collect the tissues (i.e., explants). Fragments of root (middle portion measuring $0.5 \mathrm{~cm}$ in length), hypocotyl (middle portion measuring $0.5 \mathrm{~cm}$ in length) and cotyledons (sectioned at $50 \%$ of the area) were individually inoculated in glass test tubes $(20 \times 100 \mathrm{~mm})$ containing $6 \mathrm{~mL}$ of Woody Plant Medium 
(WPM) (Lloyd and McCown 1980). The culture medium was supplemented with different combinations and concentrations of plant growth regulators, namely, 0.0, 2.0 and $4.0 \mathrm{mg} \mathrm{L}^{-1}$ of $\alpha$-naphthaleneacetic acid (NAA); 0.0, 1.0 and $2.0 \mathrm{mg} \mathrm{L}^{-1}$ of thidiazuron (TDZ); and 0.0, 1.0 and $2.0 \mathrm{mg} \mathrm{L}^{-1}$ of 2,4-dichlorophenoxyacetic acid (2,4-D). Each of the treatments consisted of 10 replicates (the experimental unit was test tubes containing one explant). The experiment was conducted in a completely randomized design in a factorial arrangement $(3 \times 27)$, where the factors were three types of explants (i.e., hypocotyl, cotyledon and root) and 27 combinations of plant growth regulators (i.e., $\mathrm{NAA} \times \mathrm{TDZ} \times 2,4-\mathrm{D})$. After inoculation, explants were kept in a growth room in the dark for 30 days. After treatments had been applied for 30 days, the percentage of callogenesis was evaluated.

Adventitious bud induction. Callus were transferred to the adventitious bud induction medium, constituted by WPM culture medium and supplemented with $1.0 \mathrm{mg} \mathrm{L}^{-1}$ of 6-benzylaminopurine (BAP). Explants were inoculated in glass containers $(6 \times 7 \mathrm{~cm})$ containing $40 \mathrm{~mL}$ of a culture medium. Subcultures were performed every 30 days under growth room conditions. The experiment was conducted in a completely randomized design in a factorial arrangement $(3 \times 27)$, where the factors were three types of explants (i.e., hypocotyl, cotyledon, and root) and 27 combinations of plant growth regulators $(\mathrm{NAA} \times \mathrm{TDZ} \times$ $2,4-\mathrm{D})$. The percentage of adventitious buds induced in 90 days was evaluated.

Shoot elongation. Only the explants that regenerated adventitious buds were used for the shoot elongation phase. Explants with initiation of 3 to 5 shoots for culture were inoculated in WPM culture medium supplemented with $0.5 \mathrm{mg} \mathrm{L}^{-1} \mathrm{BAP}$ and $1.0 \mathrm{mg} \mathrm{L}^{-1}$ of indole-3-butyric acid (IBA). Explants were inoculated in glass containers $(6 \times$ $7 \mathrm{~cm}$ ) containing $40 \mathrm{~mL}$ of culture medium. Subcultures were performed every 30 days under growth room conditions. The experiment was conducted in a completely randomized design with a factorial arrangement $(3 \times 27)$, where the factors were three types of explants (i.e., hypocotyl, cotyledon, and root) and 27 combinations of plant growth regulators $(\mathrm{NAA} \times \mathrm{TDZ} \times 2,4-\mathrm{D})$. At the end of the experiment, the number of elongated shoots $(\geq 1 \mathrm{~cm})$ in 90 days was evaluated.

Ex vitro survival, rooting and acclimatization. In vitro elongated shoots (i.e., microcuttings with a length equal to or larger than $1 \mathrm{~cm}$ ) were collected and transplanted ex vitro to a mini-incubator system (Brondani et al. 2018). The substrate used to promote the rooting of the microcuttings was a mixture of decomposed Pinus bark and medium-sized vermiculite, at a 1:1 ( $\left.\mathrm{v} \mathrm{v}^{-1}\right)$ ratio. The miniincubator system was kept under growth room conditions. The survival percentage and the adventitious roots of the microcuttings were evaluated at 20 days of ex vitro incubation. For acclimatization, the rooted plants were transplanted to individual containers $(250 \mathrm{~mL})$ containing the same proportion of the substrate used for rooting. In this phase, a nutrient solution composed of MS half-strength (Murashige and Skoog 1962) culture medium was applied every 7 days. The acclimatization period lasted 20 days. After acclimatization, the plants were transplanted to larger plastic cups $(500 \mathrm{~mL})$ and transferred to a greenhouse (50\% natural light). The growth phase in the greenhouse lasted 80 days, and plant survival was evaluated. The experiment was conducted in a completely randomized design with a factorial arrangement $(3 \times 27)$, where the factors were three types of explants (i.e., hypocotyl, cotyledon and root) and 27 combinations of plant growth regulators (i.e., NAA $\times \mathrm{TDZ} \times 2,4-\mathrm{D})$. The steps outlined in the methods section are briefly illustrated in figure 1 .

Histological analyses. Samples of the callus were fixed in a modified formaldehyde and glutaraldehyde solution (glutaraldehyde $1 \%$, paraformaldehyde $4 \%$ in sodium phosphate buffer, $\mathrm{NaH}_{2} \mathrm{PO}_{4} \cdot \mathrm{H}_{2} \mathrm{O} ; 0.1 \mathrm{M} ; \mathrm{pH}$ 7.2) (Karnovsky 1965) and were submitted to six vacuum series $(-600 \mathrm{mmHg})$ for 30 minutes each. Samples were subsequently stored for 30 days at $4{ }^{\circ} \mathrm{C}$ and dehydrated by ethanol-alcohol series in increasing concentrations (i.e., 10, 20, 30, 40, 50, 60, 70, 80, 90 and $100 \%, \mathrm{v} \mathrm{v}^{-1}$ ), remaining in each solution for 15 minutes. Samples were placed in

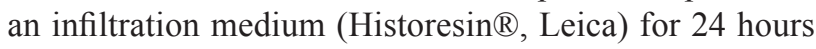
and prepared according to the manufacturer's instructions, remaining 28 days at $24{ }^{\circ} \mathrm{C}$. The blocks containing the samples were sectioned longitudinally or transversally to $5 \mu \mathrm{m}$ thickness using a Microm HM $355 \mathrm{~S}$ automatic rotary microtome (Thermo Scientific $($ ) $)$. Each section was stained with toluidine blue $\left(0.05 \%, \mathrm{v} \mathrm{v}^{-1}\right)$ in sodium phosphate buffer and citric acid (Sakai 1973) for 30 minutes and mounted on histological slides with synthetic resin $\left(\right.$ Entellan $\left.{ }^{\circledR}\right)$. The histological sections were analyzed and photographed under an optic microscope (Opton $®)$, and the images were captured at a micrometric scale. A descriptive analysis was performed on each sample, aimed at identifying the disposition of the tissues connecting the axillary buds and nodes, the region of the adventitious root emergence and evident meristematic zones.

Statistical analyses. The data measured in all experiments were analyzed using Hartley's test $(P>0.05)$ and the Shapiro-Wilk's test $(P>0.05)$ to assess the homogeneity of the variances and the normal distribution of data, respectively. Data were transformed as needed by the Box-Cox test. Next, an analysis of variance (ANOVA, $P<0.05$ ) was performed. According to the significance of ANOVA, the mean values of the treatments were compared by the Duncan's test $(P<0.05)$. The steps outlined in the methods section are briefly illustrated in figure 1 . 


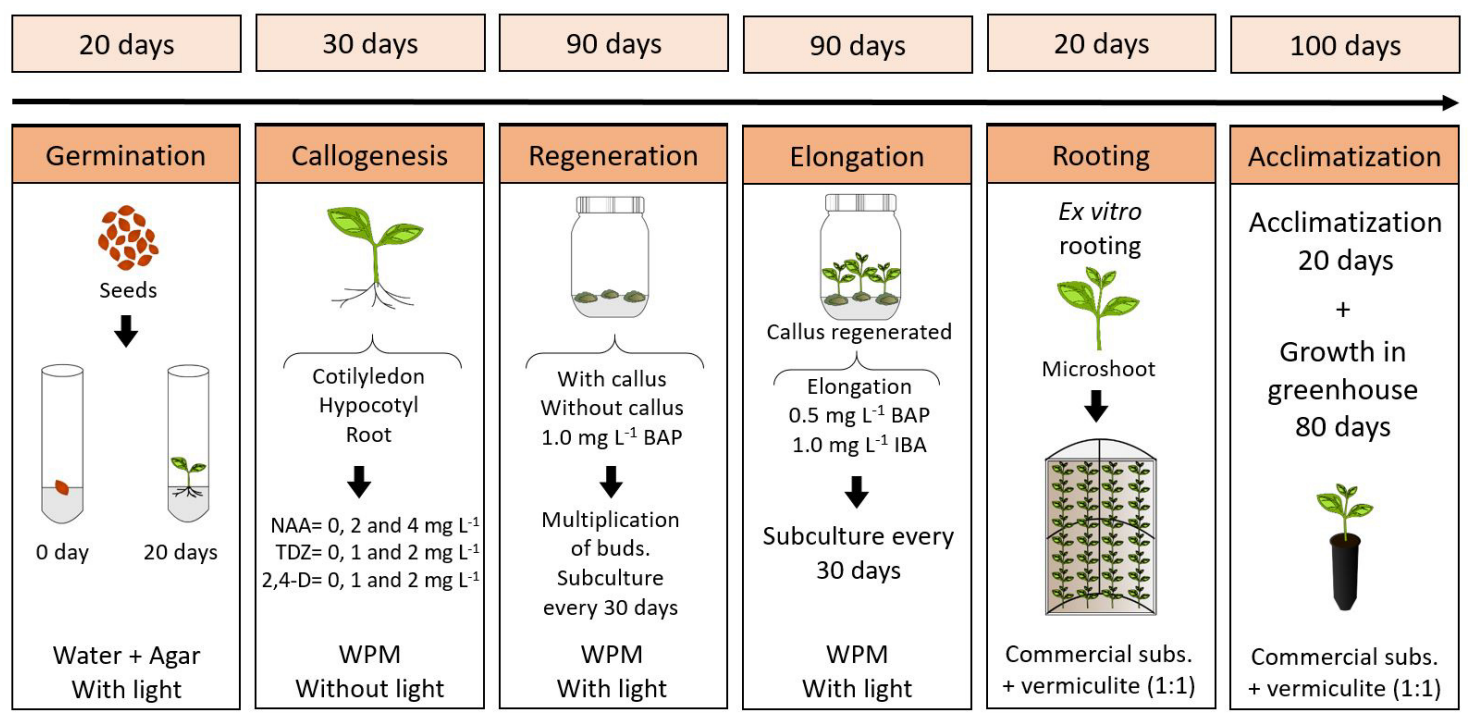

Figure 1. Flowchart of the experiment with detail of the in vitro seed inoculation phase until the acclimatization of microplants of E. cloeziana obtained by indirect regeneration in 350 days.

Diagrama de flujo del experimento con detalles de la fase de inoculación de semillas in vitro hasta la aclimatización de microplantas de E. cloeziana obtenidas por regeneración indirecta en 350 días.

\section{RESULTS}

Callus culture. Seeds of E. cloeziana were inoculated in vitro to obtain seedlings as a source of explants, and cultures with no visible microbial infection (bacteria and/or fungi) were selected. After 30 days of the callogenesis process with different tissues and combinations of plant growth regulators, induction to callogenesis was observed in all treatments, with an overall mean callogenesis of $78.4 \%$. Percentages of callogenesis of 30-100\% were observed for the hypocotyl, $40-100 \%$ for the cotyledon and $20-100 \%$ for the root (table 1).

Intense meristematic activities related to the organogenic competence of the tissues induced by combinations of plant growth regulators were observed. Cellular areas of meristematic competence were identified in the cells of the superficial tissues of callus structures, characterized by thin cell walls, reduced cell size, isodiametric cells and a high nuclear/cytoplasmatic ratio (figure 2A). In addition, the formation of a vascular bundle and the presence of a region with intense meristematic activity denotes cell competence for the formation of new tissues (figure 2A). High accumulation of ergastic substances in cells, intense meristematic activity (figure 2B) and the presence of meristemoids (figure 2C) were observed in several anatomical sections, indicating morphogenic potential.

Applications of $1.0 \mathrm{mg} \mathrm{L}^{-1} 2.4-\mathrm{D}$ and $4.0 \mathrm{mg} \mathrm{L}^{-1} \mathrm{NAA}+$ $2.0 \mathrm{mg} \mathrm{L}^{-1}$ 2,4-D provided an effective hormonal balance for the initiation of the adventitious root formation from the callus in the hypocotyl and cotyledon, respectively (figure 2D).

Adventitious root formation was observed in the hypocotyl and cotyledon (figure 3A), showing the formation of a meristematic center with a connection to the callus mass (figure 3B). High nuclear/cytoplasmic ratio was observed in isolated cells for the combination of NAA and 2,4-D in all tissues tested (figure $3 \mathrm{C}$ ). In addition, meristematic centers were also observed in the upper ends of the callus structures (figure 3D), indicating intense morphogenic activity.

Adventitious bud induction. Tissues that formed a callus were transferred to the culture medium supplemented with $1.0 \mathrm{mg} \mathrm{L}^{-1}$ BAP. Only $1.5 \%$ of the callus demonstrated organogenic competence for adventitious bud induction, where the best responses occurred for the combinations of $1.0 \mathrm{mg} \mathrm{L}^{-1} \mathrm{TDZ}, 2.0 \mathrm{mg} \mathrm{L}^{-1} \mathrm{TDZ}$ and $2.0 \mathrm{mg} \mathrm{L}^{-1} \mathrm{NAA}+2.0$ $\mathrm{mg} \mathrm{L}^{-1} \mathrm{TDZ}$. Hypocotyl and cotyledon tissues were able to form adventitious buds (table 2).

Callus formed from hypocotyl did not present a significant difference between applications of $2.0 \mathrm{mg} \mathrm{L}^{-1} \mathrm{TDZ}$ and $2.0 \mathrm{mg} \mathrm{L}^{-1} \mathrm{NAA}+2.0 \mathrm{mg} \mathrm{L}^{-1} \mathrm{TDZ}$, which resulted in mean shoot values of $22.2 \%$ and $20.0 \%$, respectively (table 2). On the other hand, among the callus obtained from the cotyledon, a significant difference was observed between the treatments that were composed by the combinations of $1.0 \mathrm{mg} \mathrm{L}^{-1} \mathrm{TDZ}$ and $2.0 \mathrm{mg} \mathrm{L}^{-1} \mathrm{TDZ}$, with the latter being more responsive to the regeneration medium, resulting in $55.5 \%$ of the callus regenerating buds (table 2). The other tissues that did not show adventitious bud regeneration in the 90-day period were discarded.

The histological sections confirmed the regeneration of adventitious buds, which originated from the callus that presented organogenic competence, thereby indicating meristematic regions (figure 4A) and the vascular connection of shoots with the cell mass of origin (figure 4B). 
Table 1. Percentage of callogenesis in E. cloeziana explants according to the combinations of plant growth regulators and explants at 30 days of in vitro cultivation.

Porcentaje de calogénesis en explantes de E. cloeziana de acuerdo con las combinaciones de reguladores del crecimiento de las plantas y explantes a los 30 días de cultivo in vitro.

\begin{tabular}{|c|c|c|c|c|c|}
\hline \multirow{2}{*}{$\begin{array}{l}\text { NAA } \\
\left(\mathrm{mg} \mathrm{L}^{-1}\right)\end{array}$} & \multirow{2}{*}{$\begin{array}{c}\text { TDZ } \\
\left(\mathrm{mg} \mathrm{L}^{-1}\right)\end{array}$} & \multirow{2}{*}{$\begin{array}{c}2,4-\mathrm{D} \\
\left(\mathrm{mg} \mathrm{L}^{-1}\right)\end{array}$} & \multicolumn{3}{|c|}{ Explant } \\
\hline & & & Hypocotyl & Cotyledon & Root \\
\hline 0.0 & 0.0 & 0.0 & MP & $66.7^{\mathrm{Ba}}( \pm 16.7)$ & $25.0^{\mathrm{DEb}}( \pm 16.4)$ \\
\hline 0.0 & 0.0 & 1.0 & $40.0^{\mathrm{CDb}}( \pm 16.3)$ & $88.9^{\mathrm{Aa}}( \pm 11.1)$ & $37.5^{\mathrm{CDb}}( \pm 18.3)$ \\
\hline 0.0 & 0.0 & 2.0 & $100.0^{\mathrm{Aa}}( \pm 0.0)$ & $100.0^{\mathrm{Aa}}( \pm 0.0)$ & $100.0^{\mathrm{Aa}}( \pm 0.0)$ \\
\hline 0.0 & 1.0 & 0.0 & $50.0^{\mathrm{Cc}}( \pm 16.7)$ & $85.7^{\mathrm{Aa}}( \pm 14.3)$ & $70.0^{\mathrm{Bb}}( \pm 15.3)$ \\
\hline 0.0 & 1.0 & 1.0 & $100.0^{\mathrm{Aa}}( \pm 0.0)$ & $100.0^{\mathrm{Aa}}( \pm 0.0)$ & $100.0^{\mathrm{Aa}}( \pm 0.0)$ \\
\hline 0.0 & 1.0 & 2.0 & $50.0^{\mathrm{Cc}}( \pm 16.7)$ & $55.6^{\mathrm{Bb}}( \pm 17.6)$ & $66.7^{\mathrm{Ba}}( \pm 16.7)$ \\
\hline 0.0 & 2.0 & 0.0 & $100.0^{\mathrm{Aa}}( \pm 0.0)$ & $100.0^{\mathrm{Aa}}( \pm 0.0)$ & $100.0^{\mathrm{Aa}}( \pm 0.0)$ \\
\hline 0.0 & 2.0 & 1.0 & $100.0^{\mathrm{Aa}}( \pm 0.0)$ & $100.0^{\mathrm{Aa}}( \pm 0.0)$ & $100.0^{\mathrm{Aa}}( \pm 0.0)$ \\
\hline 0.0 & 2.0 & 2.0 & $100.0^{\mathrm{Aa}}( \pm 0.0)$ & $100.0^{\mathrm{Aa}}( \pm 0.0)$ & $100.0^{\mathrm{Aa}}( \pm 0.0)$ \\
\hline 2.0 & 0.0 & 0.0 & $100.0^{\mathrm{Aa}}( \pm 0.0)$ & $100.0^{\mathrm{Aa}}( \pm 0.0)$ & $100.0^{\text {Aa }}( \pm 0.0)$ \\
\hline 2.0 & 0.0 & 1.0 & $100.0^{\mathrm{Aa}}( \pm 0.0)$ & $100.0^{\mathrm{Aa}}( \pm 0.0)$ & $100.0^{\text {Aa }}( \pm 0.0)$ \\
\hline 2.0 & 0.0 & 2.0 & $100.0^{\mathrm{Aa}}( \pm 0.0)$ & $100.0^{\mathrm{Aa}}( \pm 0.0)$ & $100.0^{\mathrm{Aa}}( \pm 0.0)$ \\
\hline 2.0 & 1.0 & 0.0 & $80.0^{\mathrm{Bb}}( \pm 13.3)$ & $100.0^{\mathrm{Aa}}( \pm 0.0)$ & MP \\
\hline 2.0 & 1.0 & 1.0 & $100.0^{\mathrm{Aa}}( \pm 0.0)$ & $100.0^{\mathrm{Aa}}( \pm 0.0)$ & $100.0^{\mathrm{Aa}}( \pm 0.0)$ \\
\hline 2.0 & 1.0 & 2.0 & $90.0^{\mathrm{ABb}}( \pm 10.0)$ & $100.0^{\mathrm{Aa}}( \pm 0.0)$ & $20.0^{\mathrm{Ec}}( \pm 13.3)$ \\
\hline 2.0 & 2.0 & 0.0 & $100.0^{\mathrm{Aa}}( \pm 0.0)$ & $100.0^{\mathrm{Aa}}( \pm 0.0)$ & $100.0^{\mathrm{Aa}}( \pm 0.0)$ \\
\hline 2.0 & 2.0 & 1.0 & $100.0^{\mathrm{Aa}}( \pm 0.0)$ & $100.0^{\mathrm{Aa}}( \pm 0.0)$ & $100.0^{\mathrm{Aa}}( \pm 0.0)$ \\
\hline 2.0 & 2.0 & 2.0 & $100.0^{\mathrm{Aa}}( \pm 0.0)$ & $100.0^{\mathrm{Aa}}( \pm 0.0)$ & $100.0^{\mathrm{Aa}}( \pm 0.0)$ \\
\hline 4.0 & 0.0 & 0.0 & $100.0^{\mathrm{Aa}}( \pm 0.0)$ & $100.0^{\mathrm{Aa}}( \pm 0.0)$ & $100.0^{\mathrm{Aa}}( \pm 0.0)$ \\
\hline 4.0 & 0.0 & 1.0 & $50.0^{\mathrm{cb}}( \pm 16.7)$ & $100.0^{\mathrm{Aa}}( \pm 0.0)$ & MP \\
\hline 4.0 & 0.0 & 2.0 & $90.0^{\mathrm{ABa}}( \pm 10.0)$ & $90.0^{\mathrm{Aa}}( \pm 10.0)$ & $20.0^{\mathrm{Eb}}( \pm 13.3)$ \\
\hline 4.0 & 1.0 & 0.0 & $90.0^{\mathrm{ABb}}( \pm 10.0)$ & $100.0^{\mathrm{Aa}}( \pm 0.0)$ & $40.0^{\mathrm{Cc}}( \pm 16.3)$ \\
\hline 4.0 & 1.0 & 1.0 & $90.0^{\mathrm{ABb}}( \pm 10.0)$ & $100.0^{\mathrm{Aa}}( \pm 0.0)$ & $50.0^{\mathrm{Cc}}( \pm 16.7)$ \\
\hline 4.0 & 1.0 & 2.0 & $90.0^{\mathrm{ABb}}( \pm 10.0)$ & $100.0^{\mathrm{Aa}}( \pm 0.0)$ & $100.0^{\mathrm{Aa}}( \pm 0.0)$ \\
\hline 4.0 & 2.0 & 0.0 & $40.0^{\mathrm{CDb}}( \pm 16.3)$ & $100.0^{\mathrm{Aa}}( \pm 0.0)$ & MP \\
\hline 4.0 & 2.0 & 1.0 & MP & $90.0^{\mathrm{Aa}}( \pm 10.0)$ & MP \\
\hline 4.0 & 2.0 & 2.0 & $30.0^{\mathrm{Db}}( \pm 15.3)$ & $40.0^{\mathrm{Ca}}( \pm 16.3)$ & MP \\
\hline
\end{tabular}

Means followed by the same uppercase letter in the columns and means followed by the same lowercase letter in the rows do not differ significantly by the Duncan's test at the $5 \%$ probability level. Data are expressed as the mean ( \pm standard error). MP $=$ missing parcel due to bacterial manifestation.

Despite the high callus formation intensity of the tissues by the application of plant growth regulators, the root did not present competence for the induction of adventitious buds in the regeneration medium.

Shoot elongation. Only the callus showing adventitious bud regeneration (table 2) were subdivided into standard explants with initiation of 3 to 5 shoots for culture (figure 4A).
The elongation medium was supplemented with $0.5 \mathrm{mg} \mathrm{L}^{-1}$ BAP and $1.0 \mathrm{mg} \mathrm{L}^{-1}$ IBA to establish microstumps in vitro. Hypocotyl originating from the application of $2.0 \mathrm{mg} \mathrm{L}^{-1}$ TDZ showed the highest number of elongated shoots at 90 days of culture (table 3), resulting in a mean of 41.5 shoots per explant. All callus showed the formation of shoots (i.e., microcuttings), which were collected for the rooting phase. 

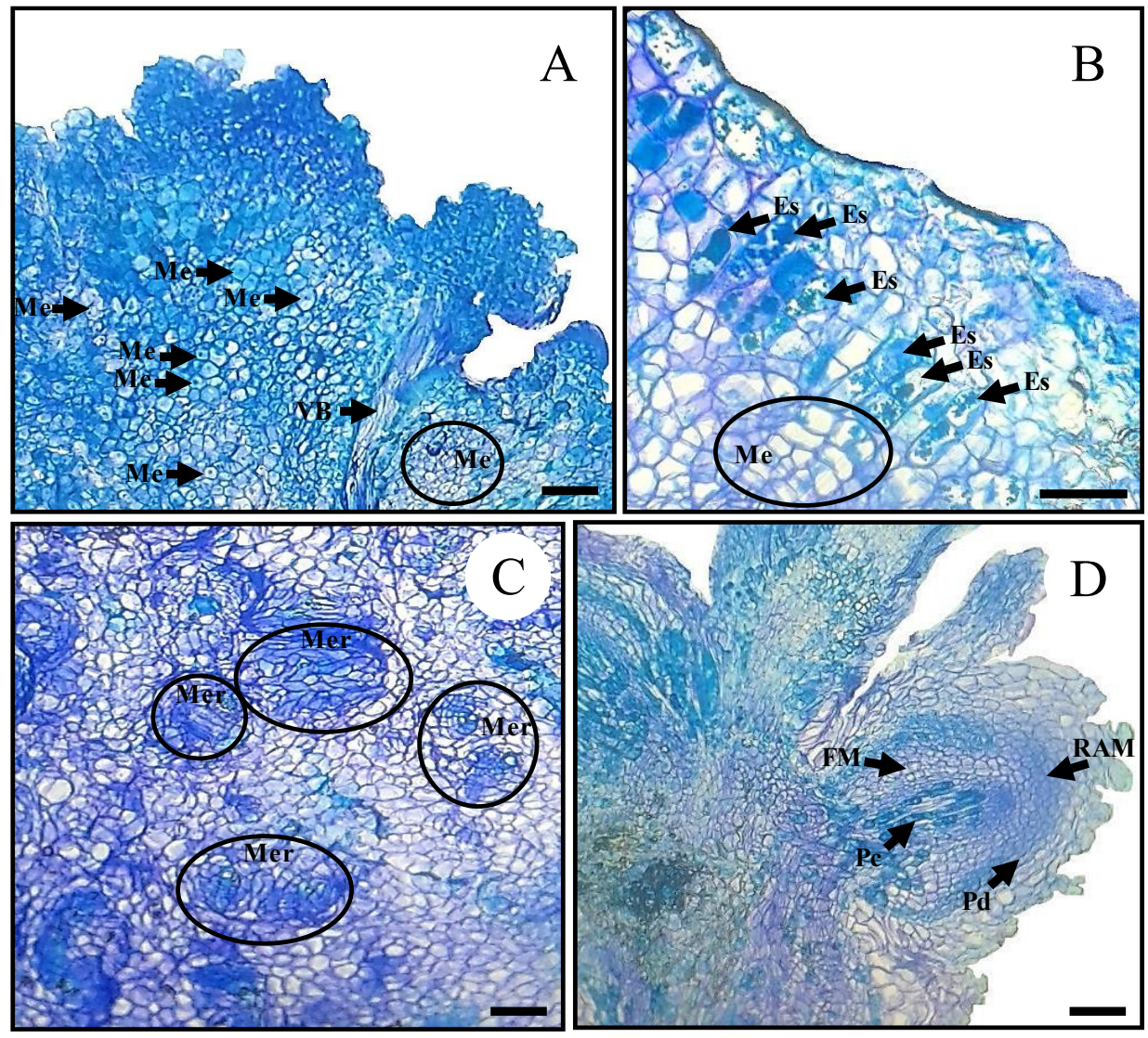

Figure 2. Histology of callus of E. cloeziana. A) Callus showing formation of a vascular bundle (arrow) and area with meristematic activity (arrow and region) supplemented with $2.0 \mathrm{mg} \mathrm{L}^{-1} \mathrm{TDZ}$ and cotyledon. B) Detail of cells showing high accumulation of ergastic substances (arrows) and a region with meristematic activity in the presence of $2.0 \mathrm{mg} \mathrm{L}^{-1} \mathrm{TDZ}$ and cotyledon. C) Region of callus showing formation of meristemoids with $1.0 \mathrm{mg} \mathrm{L}^{-1} \mathrm{TDZ}$ and cotyledon. D) Detail of the formation of adventitious roots from the callus, with the root apical meristem with $1.0 \mathrm{mg} \mathrm{L}^{-1}$ 2,4-D and hypocotyl. Vascular bundle (VB), meristematic activity (Me), ergastic substances (Es), meristemoids (Mer), root apical meristem (RAM), fundamental meristem (FM), procambium (Pc), and protoderm (Pd). Bar $=100 \mu \mathrm{m}$.

Histología de callos de E. cloeziana. A) Callo que muestra la formación de un haz vascular (flecha) y área con actividad meristemática (flecha) con suplementación de 2,0 $\mathrm{mg} \mathrm{L}^{-1}$ de TDZ y cotiledón. B) Detalle de las células que muestran una alta acumulación de sustancias ergásticas (flechas) y una región con actividad meristemática en presencia de 2,0 $\mathrm{mg} \mathrm{L}^{-1}$ de TDZ y cotiledón. C) Región del callo que muestra la formación de meristemoides con 1,0 $\mathrm{mg} \mathrm{L}^{-1}$ de TDZ y cotiledón. D) Detalle de la formación de raíces adventicias del callo, con el meristemo de la raíz apical con 1,0 $\mathrm{mg} \mathrm{L}^{-1}$ de 2,4-D e hipocotilo. Haz vascular (VB), actividad meristemática (Me), sustancias ergásticas (Es), meristemoides (Mer), meristemo de la raíz apical (RAM), meristemo fundamental $(\mathrm{FM})$, procambio $(\mathrm{Pc})$ y protodermo $(\mathrm{Pd})$. Barra $=100 \mu \mathrm{m}$.

Ex vitro survival, rooting and acclimatization. Microcuttings were collected (figure 5B) from the microstumps rooted in the shoot elongation phase (figure 5A), and these microcuttings were placed in a mini-incubator system for rooting. The mini-incubator system was maintained in a growing room under ambient conditions.

Survival and ex vitro rooting of the microcuttings (figure 5C) were evaluated at 20 days. Cotyledon subjected to $1.0 \mathrm{mg} \mathrm{L}^{-1} \mathrm{TDZ}$ and hypocotyl subjected to $2.0 \mathrm{mg} \mathrm{L}^{-1}$ TDZ showed satisfactory survival and rooting, and complete plants were obtained (table 4). The remaining combinations of plant growth regulators tested in this phase did not result in rooting, and tissue mortality was observed (table 4).
Rooted microcuttings were acclimatized for 20 days and afterwards grown in a greenhouse, where they showed normal development and growth (figure 5D), enabling completion of the adventitious regeneration protocol of plants in 350 days.

\section{DISCUSSION}

Several studies have reported on the efficiency of callus induction from hypocotyl and cotyledon with Eucalyptus species, such as those developed for E. camaldulensis Dehnh. (Dibax et al. 2010), E. saligna Smith. (Silva et al. 2015) and E. globulus Labill. (Salla et al. 2018). In the present study with E. cloeziana, callus formation occurred 


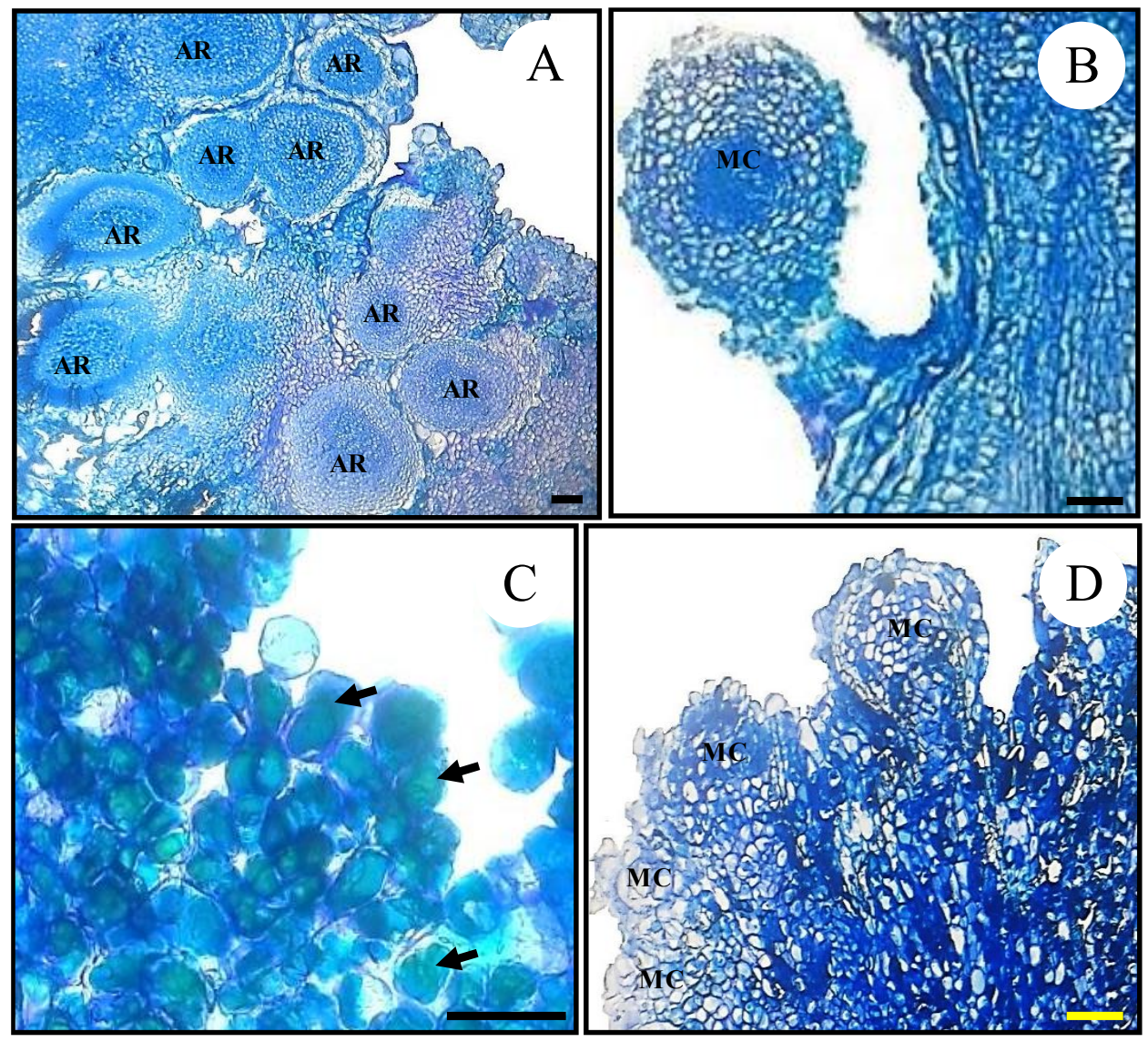

Figure 3. Histology of callus of E. cloeziana. A) Callus structure showing meristematic activities and initiation of adventitious root formation with $4.0 \mathrm{mg} \mathrm{L}^{-1} \mathrm{NAA}+2.0 \mathrm{mg} \mathrm{L}^{-1}$ 2,4-D and cotyledon. B) Evidence of meristematic center showing connection with the callus mass with $1.0 \mathrm{mg} \mathrm{L}^{-1} \mathrm{TDZ}$ and cotyledon. C) Presence of isolated cells with high nuclear/cytoplasmic ratio (arrows) with 4.0 mg L ${ }^{-1} \mathrm{NAA}+2.0 \mathrm{mg} \mathrm{L}^{-1}$ 2,4-D and cotyledon. D) Evidence of meristematic center at the upper ends of the callus mass with $2.0 \mathrm{mg}$ $\mathrm{L}^{-1} \mathrm{TDZ}$ and cotyledon. Adventitious root (AR), meristematic center (MC). Bar $=100 \mu \mathrm{m}$.

Histología de callos de E. cloeziana. A) Estructura del callo que muestra actividades meristemáticas e iniciación de la formación de raíces adventícias con 4,0 $\mathrm{mg} \mathrm{L}^{-1}$ de ANA + 2,0 $\mathrm{mg} \mathrm{L}^{-1}$ de 2,4-D y cotiledón. B) Evidencia de centro meristemático que muestra conexión con la masa de callos con $1,0 \mathrm{mg} \mathrm{L}^{-1}$ de TDZ y cotiledón. C) Presencia de células aisladas con alta relación nuclear/citoplasmática (flechas) con $4,0 \mathrm{mg} \mathrm{L}^{-1} \mathrm{de}$ ANA $+2,0$ $\mathrm{mg} \mathrm{L}^{-1}$ de 2,4-D y cotiledón. D) Evidencia de centro meristemático en los extremos superiores de la masa del callo con 2,0 $\mathrm{mg} \mathrm{L}^{-1}$ de TDZ y cotiledón. Raíces adventicias (AR), centro meristemático (MC). Barra $=100 \mu \mathrm{m}$.

in all tissues tested, independent from the plant growth regulator combinations; however, the highest percentages of callogenesis were observed when cotyledon tissue was used (table 1).

Hypocotyl and cotyledon extracted from E. cloeziana seedlings were the sources of explants most suitable for callus formation, including evidence of adventitious root induction and buds at this organogenic phase. Vascular bundle formation and an area with meristematic activity in the callus were observed with the combination of 2.0 $\mathrm{mg} \mathrm{L}^{-1} \mathrm{TDZ}$ and the cotyledon (figure 2A). Aggarwal et al. (2010) found intense meristematic activity in cells of the superficial layer in tissues of E. tereticornis Smith., and these cells were later organized into buds. This observation was also reported in E. cloeziana, both for root and bud formation (figures 2A-D). In addition, a high accumulation of ergastic substances in callus from cotyledon combined with $2.0 \mathrm{mg} \mathrm{L}^{-1} \mathrm{TDZ}$ (figure 2B) and callus showing the formation of meristems in the combination of $1.0 \mathrm{mg} \mathrm{L}^{-1}$ TDZ and cotyledon (figure 2C) were observed. In a study on the induction of callus with BAP and NAA and/or IAA (indole-3-acetic acid) in E. dunnii Maiden., Oberschelp et al. (2015) observed the presence of subepidermal meristemoids and meristematic areas developing at the end of the hypocotyl and evidence of a high number of druses in buds or ergastic substance, observations similar to those made in the present study with E. cloeziana. Initiation of adventitious root occurred from the callus in the hypocotyl and cotyledon (figures $2 \mathrm{D}$ and $3 \mathrm{~A}$ ).

The presence of a meristematic center with a vascular connection to the callus mass was observed in cotyledon treated with $1.0 \mathrm{mg} \mathrm{L}^{-1} \mathrm{TDZ}$ (figure 3B) and $2.0 \mathrm{mg} \mathrm{L}^{-1}$ 
Table 2. Percentage of induction of adventitious buds in E. cloeziana explants according to the combinations of plant growth regulators and explants at 90 days of in vitro cultivation.

Porcentaje de inducción de yemas adventicias en explantes de E. cloeziana de acuerdo con las combinaciones de reguladores del crecimiento de las plantas y explantes a los 90 días de cultivo in vitro.

\begin{tabular}{|c|c|c|c|c|c|}
\hline \multirow{2}{*}{$\begin{array}{c}\text { NAA } \\
\left(\mathrm{mg} \mathrm{L}^{-1}\right)\end{array}$} & \multirow{2}{*}{$\begin{array}{c}\mathrm{TDZ} \\
\left(\mathrm{mg} \mathrm{L}^{-1}\right)\end{array}$} & \multirow{2}{*}{$\begin{array}{c}2,4-\mathrm{D} \\
\left(\mathrm{mg} \mathrm{L}^{-1}\right)\end{array}$} & \multicolumn{3}{|c|}{ Explant } \\
\hline & & & Hypocotyl & Cotyledon & Root \\
\hline 0.0 & 0.0 & 0.0 & MP & $0.0^{\mathrm{Ca}}( \pm 0.0)$ & $0.0^{\text {Aa }}( \pm 0.0)$ \\
\hline 0.0 & 0.0 & 1.0 & $0.0^{\mathrm{Ba}}( \pm 0.0)$ & $0.0^{\mathrm{Ca}}( \pm 0.0)$ & $0.0^{\mathrm{Aa}}( \pm 0.0)$ \\
\hline 0.0 & 0.0 & 2.0 & $0.0^{\mathrm{Ba}}( \pm 0.0)$ & $0.0^{\mathrm{Ca}}( \pm 0.0)$ & $0.0^{\mathrm{Aa}}( \pm 0.0)$ \\
\hline 0.0 & 1.0 & 0.0 & $0.0^{\mathrm{Bb}}( \pm 0.0)$ & $42.8^{\mathrm{Ba}}( \pm 20.2)$ & $0.0^{\mathrm{Ab}}( \pm 0.0)$ \\
\hline 0.0 & 1.0 & 1.0 & $0.0^{\mathrm{Ba}}( \pm 0.0)$ & $0.0^{\mathrm{Ca}}( \pm 0.0)$ & $0.0^{\mathrm{Aa}}( \pm 0.0)$ \\
\hline 0.0 & 1.0 & 2.0 & $0.0^{\mathrm{Ba}}( \pm 0.0)$ & $0.0^{\mathrm{Ca}}( \pm 0.0)$ & $0.0^{\text {Aa }}( \pm 0.0)$ \\
\hline 0.0 & 2.0 & 0.0 & $22.2^{\mathrm{Ab}}( \pm 14.7)$ & $55.5^{\mathrm{Aa}}( \pm 17.5)$ & $0.0^{\mathrm{Ac}}( \pm 0.0)$ \\
\hline 0.0 & 2.0 & 1.0 & $0.0^{\mathrm{Ba}}( \pm 0.0)$ & $0.0^{\mathrm{Ca}}( \pm 0.0)$ & $0.0^{\mathrm{Aa}}( \pm 0.0)$ \\
\hline 0.0 & 2.0 & 2.0 & $0.0^{\mathrm{Ba}}( \pm 0.0)$ & $0.0^{\mathrm{Ca}}( \pm 0.0)$ & $0.0^{\mathrm{Aa}}( \pm 0.0)$ \\
\hline 2.0 & 0.0 & 0.0 & $0.0^{\mathrm{Ba}}( \pm 0.0)$ & $0.0^{\mathrm{Ca}}( \pm 0.0)$ & $0.0^{\mathrm{Aa}}( \pm 0.0)$ \\
\hline 2.0 & 0.0 & 1.0 & $0.0^{\mathrm{Ba}}( \pm 0.0)$ & $0.0^{\mathrm{Ca}}( \pm 0.0)$ & $0.0^{\text {Aa }}( \pm 0.0)$ \\
\hline 2.0 & 0.0 & 2.0 & $0.0^{\mathrm{Ba}}( \pm 0.0)$ & $0.0^{\mathrm{Ca}}( \pm 0.0)$ & $0.0^{\mathrm{Aa}}( \pm 0.0)$ \\
\hline 2.0 & 1.0 & 0.0 & $0.0^{\mathrm{Ba}}( \pm 0.0)$ & $0.0^{\mathrm{Ca}}( \pm 0.0)$ & MP \\
\hline 2.0 & 1.0 & 1.0 & $0.0^{\mathrm{Ba}}( \pm 0.0)$ & $0.0^{\mathrm{Ca}}( \pm 0.0)$ & $0.0^{\mathrm{Aa}}( \pm 0.0)$ \\
\hline 2.0 & 1.0 & 2.0 & $0.0^{\mathrm{Ba}}( \pm 0.0)$ & $0.0^{\mathrm{Ca}}( \pm 0.0)$ & $0.0^{\mathrm{Aa}}( \pm 0.0)$ \\
\hline 2.0 & 2.0 & 0.0 & $20.0^{\mathrm{Aa}}( \pm 13.3)$ & $0.0^{\mathrm{Cb}}( \pm 0.0)$ & $0.0^{\mathrm{Ab}}( \pm 0.0)$ \\
\hline 2.0 & 2.0 & 1.0 & $0.0^{\mathrm{Ba}}( \pm 0.0)$ & $0.0^{\mathrm{Ca}}( \pm 0.0)$ & $0.0^{\mathrm{Aa}}( \pm 0.0)$ \\
\hline 2.0 & 2.0 & 2.0 & $0.0^{\mathrm{Ba}}( \pm 0.0)$ & $0.0^{\mathrm{Ca}}( \pm 0.0)$ & $0.0^{\mathrm{Aa}}( \pm 0.0)$ \\
\hline 4.0 & 0.0 & 0.0 & $0.0^{\mathrm{Ba}}( \pm 0.0)$ & $0.0^{\mathrm{Ca}}( \pm 0.0)$ & $0.0^{\text {Aa }}( \pm 0.0)$ \\
\hline 4.0 & 0.0 & 1.0 & $0.0^{\mathrm{Ba}}( \pm 0.0)$ & $0.0^{\mathrm{Ca}}( \pm 0.0)$ & MP \\
\hline 4.0 & 0.0 & 2.0 & $0.0^{\mathrm{Ba}}( \pm 0.0)$ & $0.0^{\mathrm{Ca}}( \pm 0.0)$ & $0.0^{\mathrm{Aa}}( \pm 0.0)$ \\
\hline 4.0 & 1.0 & 0.0 & $0.0^{\mathrm{Ba}}( \pm 0.0)$ & $0.0^{\mathrm{Ca}}( \pm 0.0)$ & $0.0^{\mathrm{Aa}}( \pm 0.0)$ \\
\hline 4.0 & 1.0 & 1.0 & $0.0^{\mathrm{Ba}}( \pm 0.0)$ & $0.0^{\mathrm{Ca}}( \pm 0.0)$ & $0.0^{\mathrm{Aa}}( \pm 0.0)$ \\
\hline 4.0 & 1.0 & 2.0 & $0.0^{\mathrm{Ba}}( \pm 0.0)$ & $0.0^{\mathrm{Ca}}( \pm 0.0)$ & $0.0^{\mathrm{Aa}}( \pm 0.0)$ \\
\hline 4.0 & 2.0 & 0.0 & $0.0^{\mathrm{Ba}}( \pm 0.0)$ & $0.0^{\mathrm{Ca}}( \pm 0.0)$ & $\mathrm{MP}$ \\
\hline 4.0 & 2.0 & 1.0 & MP & $0.0^{\mathrm{Ca}}( \pm 0.0)$ & MP \\
\hline 4.0 & 2.0 & 2.0 & $0.0^{\mathrm{Ba}}( \pm 0.0)$ & $0.0^{\mathrm{Ca}}( \pm 0.0)$ & MP \\
\hline
\end{tabular}

Means followed by the same uppercase letter in the columns and means followed by the same lowercase letter in the rows do not differ significantly by the Duncan's test at the $5 \%$ probability level. Data are expressed as the mean ( \pm standard error). MP = missing parcel due to bacterial manifestation.

Table 3. Number of elongated shoots per E. cloeziana explant according to combination of plant growth regulators and explants at 90 days of in vitro culture.

Número de brotes alargados por explante de E. cloeziana de acuerdo con la combinación de reguladores del crecimiento de las plantas y explantes a los 90 días de cultivo in vitro.

\begin{tabular}{cccc}
\hline NAA $\left(\mathrm{mg} \mathrm{L}^{-1}\right)$ & TDZ $\left(\mathrm{mg} \mathrm{L}^{-1}\right)$ & Explant & Shoot number $\left(\right.$ shoot explant $\left.{ }^{-1}\right)$ \\
\hline 0.0 & 1.0 & Cotyledon & $20.0^{\mathrm{B}}( \pm 3.5)$ \\
0.0 & 2.0 & Hypocotyl & $41.5^{\mathrm{A}}( \pm 16.5)$ \\
0.0 & 2.0 & Cotyledon & $12.0^{\mathrm{B}}( \pm 2.9)$ \\
2.0 & 2.0 & Hypocotyl & $9.5^{\mathrm{C}}( \pm 3.5)$ \\
\hline
\end{tabular}

Means followed by the same uppercase letter do not differ significantly by the Duncan's test at the $5 \%$ probability level. Data are expressed as the mean ( \pm standard error). 

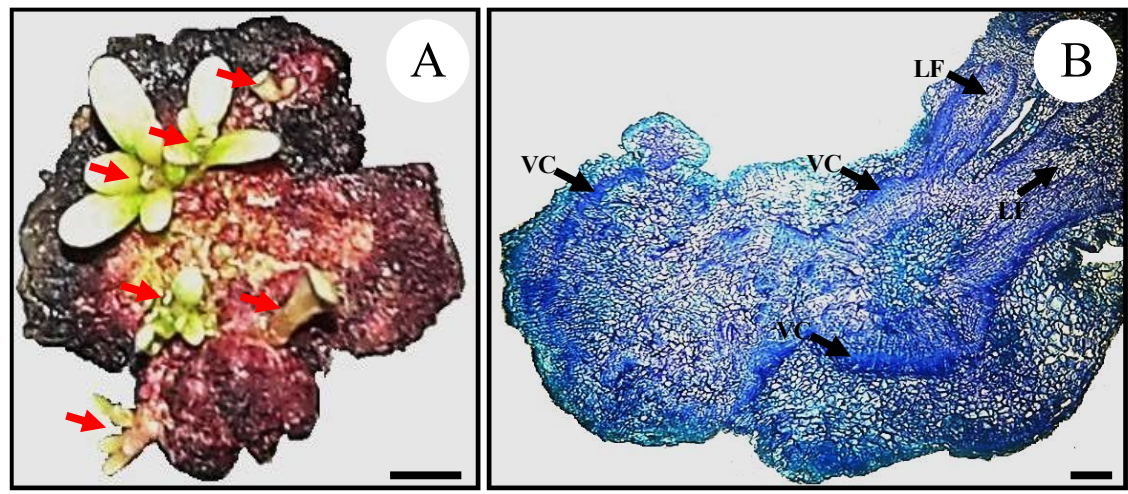

Figure 4. Histology of organogenic callus of E. cloeziana obtained from the combination of $2.0 \mathrm{mg} \mathrm{L}^{-1} \mathrm{TDZ}$ and hypocotyl. A) Details on the induction of adventitious buds with shoot initiation, leaves and apical meristem (arrows). Bar $=1 \mathrm{~cm}$. B) Adventitious leaf primordia showing vascular connection with the callus mass. Adventitious leaf primordia (LF), vascular connection $(\mathrm{VC}) . \mathrm{Bar}=100 \mu \mathrm{m}$.

Histología de callos organogénicos de E. cloeziana obtenidos de la combinación de 2,0 mg L-1 de TDZ y hipocotílico. A) Detalles sobre la inducción de yemas adventicias con iniciación de brotes, hojas y el meristemo apical (flechas). Barra $=1 \mathrm{~cm}$. B) Primordios de hojas adventicias que muestran conexión vascular con la masa del callos. Primordios de hojas adventicias (LF), conexión vascular (VC). Barra $=100 \mu \mathrm{m}$.

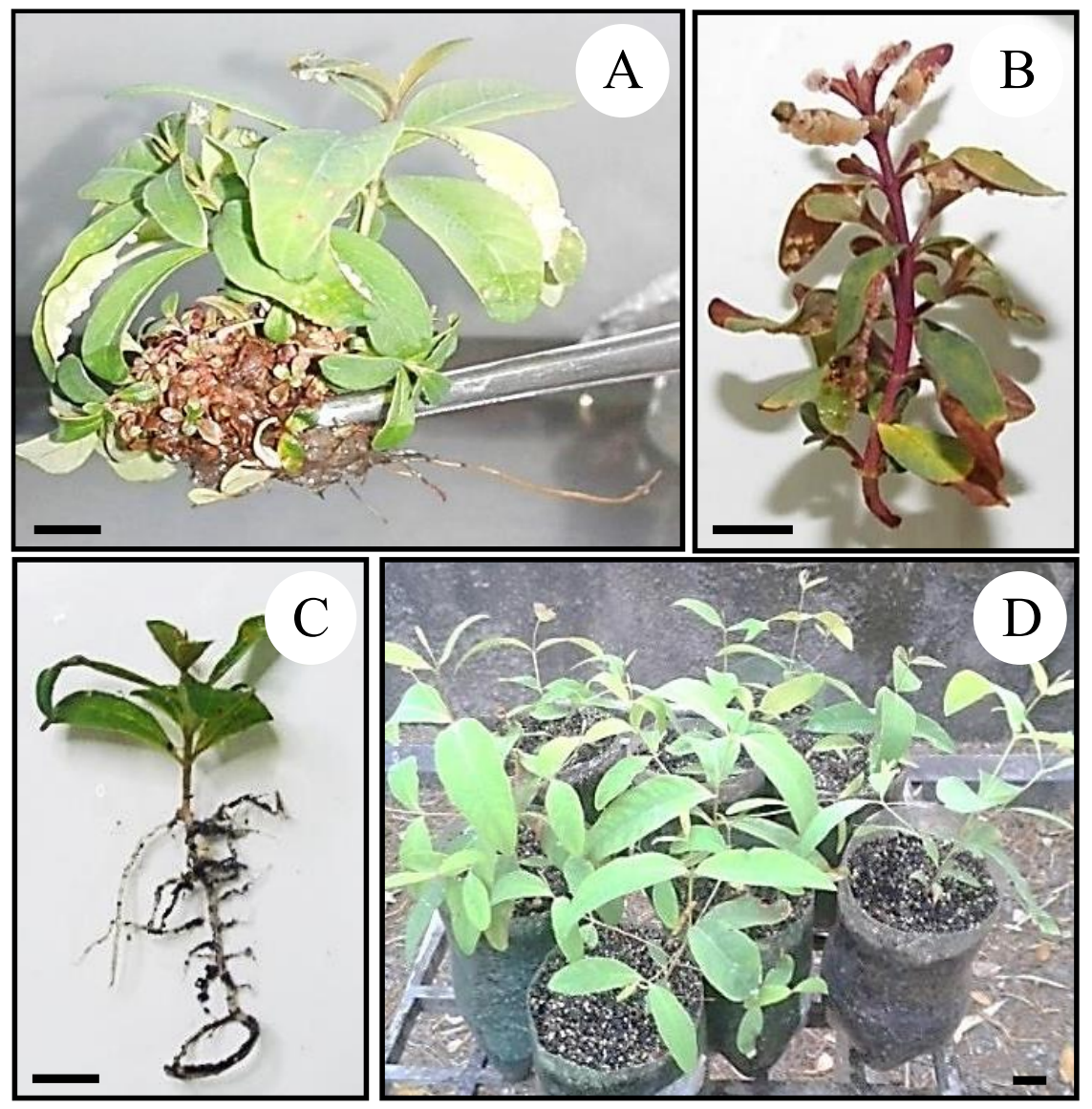

Figure 5. Stages of shoot elongation and ex vitro rooting of E. cloeziana. A) Details of in vitro rooted microstump, with visible formations of shoots. Bar $=1 \mathrm{~cm}$. B) Details of a shoot collected (i.e., microcutting) from a microstump where callus structures were present on the leaves. Bar $=1 \mathrm{~cm}$. C) Details of microcutting rooted under ex vitro conditions at 20 days. Bar $=1 \mathrm{~cm}$. D) Acclimatized plants grown in a greenhouse at 100 days. $\mathrm{Bar}=2 \mathrm{~cm}$.

Etapas de alargamiento de brotes y enraizamiento ex vitro de E. cloeziana. A) Detalles del microcepa enraizado in vitro, con formaciones visibles de brotes alargados. Barra $=1 \mathrm{~cm}$. B) Detalles de un brote recogido (microestaca) de una microcepa donde las estructuras de callos estaban presentes en las hojas. Barra $=1 \mathrm{~cm}$. C) Detalles de microestaca enraizado en condiciones ex vitro a los 20 días. Barra $=1 \mathrm{~cm}$. D) Plantas climatizadas cultivadas en un invernadero por 100 días. Barra $=2 \mathrm{~cm}$. 
Table 4. Percentage of survival and ex vitro rooting of E. cloeziana microcuttings according to the concentration of plant growth regulators and explants at 20 days of cultivation.

Porcentaje de supervivencia y enraizamiento ex vitro de microestaca de E. cloeziana de acuerdo con la concentración de reguladores del crecimiento de las plantas y explantes a los 20 días de cultivo.

\begin{tabular}{ccccc}
\hline NAA $\left(\mathrm{mg} \mathrm{L}^{-1}\right)$ & TDZ $\left(\mathrm{mg} \mathrm{L}^{-1}\right)$ & Explant & Survival $(\%)$ & Rooting $(\%)$ \\
\hline 0.0 & 1.0 & Cotyledon & $66.7^{\mathrm{B}}( \pm 12.6)$ & $53.3^{\mathrm{A}}( \pm 13.3)$ \\
0.0 & 2.0 & Hypocotyl & $100.0^{\mathrm{A}}( \pm 0.0)$ & $55.6^{\mathrm{A}}( \pm 17.6)$ \\
0.0 & 2.0 & Cotyledon & $0.0^{\mathrm{C}}( \pm 0.0)$ & $0.0^{\mathrm{B}}( \pm 0.0)$ \\
2.0 & 2.0 & Hypocotyl & $0.0^{\mathrm{C}}( \pm 0.0)$ & $0.0^{\mathrm{B}}( \pm 0.0)$ \\
\hline
\end{tabular}

Means followed by the same uppercase letter in the columns do not differ significantly by the Duncan's test at the $5 \%$ probability level. Data are expressed as the mean ( \pm standard error).

TDZ (figure 3D), which can regenerate buds. This characteristic is important for the plant regeneration, such as reported by Mycock and Watt (2012), when evaluating the callus anatomy in E. grandis W. Hill ex Maiden $\times$ E. urophylla S. T. Blake observed that the roots developed from the stem region immediately above the callus or from the callus itself and that of the primordial meristems of the root appear to have been derived from the pericycle of the stem, i.e., from the parenchyma layer between the endodermis and the phloem.

The efficiency of in vitro organogenesis depends primarily on the source of the explant, on the components of the culture medium and on the environmental conditions (Hesami and Daneshvar 2018, Silva et al. 2019). Another factor influencing the organogenic responses in Eucalyptus is the endogenous and exogenous hormonal balance between the cytokinin and auxin present in the plant tissue, which serve as inducing agents for in vitro morphogenesis (Silva et al. 2019, Souza et al. 2019). Many studies report a favorable effect of TDZ at different stages of callus formation (Jafari et al. 2017), with TDZ concentrations below $2.5 \mathrm{mg} \mathrm{L}^{-1}$, being recommended for effective applications to the tissue of woody species, since high concentrations of this plant growth regulator may limit the indirect organogenesis by reducing the induction of buds and increasing hyperhydricity (Hesami and Daneshvar 2018). At 90 days after the start of the experiment, the combination of plant growth regulators and type of explants had an effect on the indirect organogenesis in E. cloeziana. In this context, the use of 1.0 and $2.0 \mathrm{mg} \mathrm{L}^{-1}$ TDZ, considering cotyledon and hypocotyl, respectively, produced the best responses due to the higher percentage of adventitious buds compared to the other evaluated treatments (table 2, figures 4A-B).

As for the number of elongated shoots arising from bud regeneration from callus, the best results were observed with the use of $2.0 \mathrm{mg} \mathrm{L}^{-1} \mathrm{TDZ}$, using hypocotyl (table 3). Data reported in literature corroborate those found in this study, since TDZ promotes cell division (Fernando et al. 2016, Jafari et al. 2017). Some studies have identified TDZ as one of the most effective cytokinins for bud regeneration in Eucalyptus. The efficiency of TDZ was demonstrated in other species of the genus Eucalyptus, such as in E. camaldulensis (Dibax et al. 2010). This ability of the callogenic tissues to redifferentiate into buds is essential for the shoot elongation phase (Salla et al. 2018).

Hypocotyl and cotyledon combined with TDZ (i.e., 1.0 and $2.0 \mathrm{mg} \mathrm{L}^{-1} \mathrm{TDZ}$ ) favored the ex vitro microcuttings survival (66.7-100.0\%) and adventitious rooting (53.3-55.6\%) (table 4). These results confirm the need for an adequate choice of plant growth regulator and tissue for the development of a protocol aiming at whole plant regeneration. The successful regeneration of plants through indirect organogenesis has been reported for a limited number of commercially important eucalypt species.

Hypocotyl and cotyledon of in vitro cultured seedlings were the most responsive tissues as explants for the regeneration of new E. cloeziana plants via indirect organogenesis, showing a response similar to that of other studies (Mittal and Sharma 2017). A possible cause for this tissue differentiation, considering that these events may vary according to the plant genotype (Salla et al. 2018), is related to the regulation of physiological processes that favor the formation of new tissues because they contain cells with high juvenility and cellular competence (Wendling et al. 2015), leading to increased organ production and development (Gupta and Karmakar 2017).

Ex vitro survival and rooting of E. cloeziana microcuttings obtained by indirect organogenesis is difficult to achieve; however, the efficiency of this protocol was observed in 350 days (figures 5A-D). Rooting is one of the most difficult phases of micropropagation of woody species and is usually conducted under ex vitro conditions (Brondani et al. 2012, 2018). However, modifications in the rooting procedures have allowed results to be obtained at adequate levels (Brondani et al. 2012), whereby various combinations of plant growth regulators can be effective in promoting survival and plant rooting through 
indirect organogenesis (Aggarwal et al. 2010, Oliveira et al. 2015).

The use of the mini-incubator system was adequate for the survival, rooting and initial acclimatization of $E$. cloeziana plants (table 4). These results corroborate other studies using the same type of system, where higher survival and rooting in microcuttings of Corymbia citriodora, E. urophylla, E. benthamii (Brondani et al. 2012, 2018) and E. cloeziana (Oliveira et al. 2015) were obtained.

Regarding the in vitro culture time, considering the phases of germination (20 days), callogenesis (30 days), bud regeneration (90 days), shoot elongation (90 days), ex vitro survival and rooting (20 days), and acclimatization (20 days) and hardening (80 days), the protocol proposed (350 days) can be considered an alternative for the propagation of the species for numerous applications within forest tree breeding.

The developed methodology can be tested in other Eucalyptus and Corymbia species that present rooting difficulties, considering that, in the current processes of in vitro rejuvenation, between 12 and 19 successive subcultures (360 to 523 days) are commonly used to obtain juvenility/reinvigoration of the mature tissues and, consequently, to increase the rhizogenic competence of the propagules. Notably, the protocol was developed for explants collected from seedlings obtained by in vitro germination, and thus, the feasibility of applying the technique to selected adult plants needs to be tested.

In conclusion for E. cloeziana, ( $i$ ) tissue competence and plant growth regulator concentrations were effective for the induction of callus structures; (ii) meristematic center and high nuclear/cytoplasmic ratio were observed in the combination of NAA and 2,4-D; (iii) in vitro adventitious bud induction and shoot elongation occurred with $1.0 \mathrm{mg} \mathrm{L}^{-1} \mathrm{TDZ}$ combined with cotyledon, $2.0 \mathrm{mg} \mathrm{L}^{-1}$ TDZ combined with hypocotyl and cotyledon, and $2.0 \mathrm{mg}$ $\mathrm{L}^{-1} \mathrm{NAA}+2.0 \mathrm{mg} \mathrm{L}^{-1} \mathrm{TDZ}$ combined with hypocotyl; (iv) cotyledon combined with $1.0 \mathrm{mg} \mathrm{L}^{-1} \mathrm{TDZ}$ and hypocotyl combined with $2.0 \mathrm{mg} \mathrm{L}^{-1} \mathrm{TDZ}$ were characterized by the ex vitro survival of microcuttings (66.7-100.0\%) and by adventitious rooting (53.3-55.6\%).

\section{ACKNOWLEDGMENTS}

We thank the National Council for Scientific and Technological Development, Brazil (Conselho Nacional de Desenvolvimento Científico e Tecnológico - CNPq), Coordination for Improvement of Higher Education Personnel, Brazil (Coordenação de Aperfeiçoamento de Pessoal de Nível Superior - CAPES), Foundation for Research of the State of Minas Gerais, Brazil (Fundação de Amparo a Pesquisa do Estado de Minas Gerais - FAPEMIG) and PAEC OEA/GCUB for their financial support and scholarships for the students. We thank the Forestry Science and Research Institute, Brazil (Instituto de Pesquisas e Estudos Florestais - IPEF) for donating seeds.

\section{REFERENCES}

Aggarwal D, A Kumar, MS Reddy. 2010. Shoot organogenesis in elite clones of Eucalyptus tereticornis. Plant Cell, Tissue and Organ Culture 102(1): 45-52. DOI: 10.1007/s11240010-9703-y

Alves RC, ALC Oliveira, EVM Carrasco. 2017. Propriedades físicas da madeira de Eucalyptus cloeziana F. Muell. Floresta e Ambiente 24: e00015312. DOI: 10.1590/2179$\underline{8087.015312}$

Arriel TG, FMG Ramalho, RAB Lima, KIR Sousa, PRG Hein, PF Trugilho. 2019. Developing near infrared spectroscopic models for predicting density of Eucalyptus wood based on indirect measurement. Cerne 25(3): 294-300. DOI: $\underline{10.1590 / 01047760201925032646}$

Brondani GE, HW Wit Ondas, FJB Baccarin, AN Gonçalves, M Almeida. 2012. Micropropagation of Eucalyptus benthamii to form a clonal micro-garden. In Vitro Cellular \& Developmental Biology - Plant 48(5): 478-487. DOI: $10.1007 /$ s11627-012-9449-9

Brondani GE, LS Oliveira, ER Konzen, ALL Silva, JC Costa. 2018. Mini-incubators improve the adventitious rooting performance of Corymbia and Eucalyptus microcuttings according to the environment in which they are conditioned. Anais da Academia Brasileira de Ciências 90(2, suppl.1): 2409-2423. DOI: 10.1590/0001-3765201720170284

Dibax R, RC Quisen, C Bona, M Quoirin. 2010. Plant regeneration from cotyledonary explants of Eucalyptus camaldulensis Dehn and histological study of organogenesis in vitro. Brazilian Archives of Biology and Technology 53(2): 311318. DOI: $10.1590 / \mathrm{S} 1516-89132010000200009$

Fernando SC, QD Jason, JQD Goodger, SS Gutierrez, AAT Johnson, I Woodrow. 2016. Plant regeneration through indirect organogenesis and genetic transformation of Eucalyptus polybractea R. T. Baker. Industrial Crops and Products 86: 73-78. DOI: 10.1016/j.indcrop.2016.03.025

Gupta SD, D Karmakar. 2017. Machine vision based evaluation of impact of light emitting diodes (LEDs) on shoot regeneration and the effect of spectral quality on phenolic content and antioxidant capacity in Swertia chirata. Journal of Photochemistry and Photobiology B: Biology 174: 162172. DOI: $10.1016 /$ j.jphotobiol.2017.07.029

Hesami M, MH Daneshvar. 2018. In vitro adventitious shoot regeneration through direct and indirect organogenesis from seedling-derived hypocotyl segments of Ficus religiosa L.: an important medicinal plant. HortScience 53(1): 55-61. DOI: 10.21273/HORTSCI12637-17

Jafari M, MH Daneshvar, A Lotfi. 2017. In vitro shoot proliferation of Passiflora caerulea L. via cotyledonary node and shoot tip explants. BioTechnologia 98(2): 113-119. DOI: $\underline{10.5114 / \mathrm{bta} .2017 .68310}$

Karnovsky MJ. 1965. A formaldehyde-glutaraldehyde fixative of high osmolality for use in electron microscopy. The Journal of Cell Biology 27: 137-138. https://www.jstor.org/sta$\underline{\text { ble } / 1604673}$

Lloyd G, B McCown. 1980. Commercially-feasible micropropagation of mountain laurel Kalmia latifolia by use of shoottip culture. Combined Proceedings, International Plant Propagators Society 30: 421-427. https://www.pubhort. org/ipps/30/99.htm

Mittal J, MM Sharma. 2017. Enhanced production of berberine 
in in vitro regenerated cell of Tinospora cordifolia and its analysis through LCMS QToF. 3 Biotech 7(25): 1-12. DOI: 10.1007/s13205-016-0592-6

Murashige T, F Skoog. 1962. A revised medium for rapid growth and bioassays with tobacco tissue cultures. Physiologia Plantarum 15(3): 473-497. DOI: 10.1111/j.13993054.1962.tb08052.x

Mutawil AC, F Vinale, F Halleen, M Lorito, L Mostert. 2016. Isolation, production and in vitro effects of the major secondary metabolite produced by Trichoderma species used for the control of grapevine trunk diseases. Plant Pathology 65(1): 104-113. DOI: $10.1111 /$ ppa. 12385

Mycock DJ, MP Watt. 2012. Shoot and root morphogenesis from Eucalyptus grandis $\times$ E. urophylla callus. African Journal of Biotechnology 11(101): 16669-16676. https://www.ajol. info/index.php/ajb/article/view/130019

Oberschelp GPJ, AN Gonçalves, EC Meneghetti, EM Graner, M Almeida. 2015. Eucalyptus dunnii Maiden plant regeneration via shoot organogenesis on a new basal medium based on the mineral composition of young stump shoots. In Vitro Cellular \& Developmental Biology - Plant 51(6): 626-636. DOI: $10.1007 / \mathrm{s} 11627-015-9715-8$

Oliveira LS, GE Brondani, KD Batagin-Piotto, R Calsavara, AN Gonçalves, M Almeida. 2015. Micropropagation of Eucalyptus cloeziana mature trees. Australian Forestry 78(4): 219-231. DOI: 10.1080/00049158.2015.1073211

Pan Z, S Zhu, R Guan, X Deng. 2010. Identification of $24-D-r e s-$ ponsive proteins in embryogenic callus of Valencia sweet orange (Citrus sinensis Osbeck) following osmotic stress. Plant Cell, Tissue and Organ Culture 103(2): 145-153.
DOI: $10.1007 / \mathrm{s} 11240-010-9762-0$

Sakai WS. 1973. Simple method for differential staining of paraffin embedded plant material using toluidine blue O. Biotechnic and Histochemistry 48(5): 247-249. DOI: $10.3109 / 10520297309116632$

Salla TD, CS Silva, KLG Machado, LV Astarita, ER Santarém. 2018. Non-aerated liquid culture promotes shoot organogenesis in Eucalyptus globulus Labill. Journal of Forestry Research 29(3): 623-629. DOI: 10.1007/s11676-017-0485-5

Silva ALL, AL Gollo, GE Brondani, MA Horbach, LS Oliveira, MP Machado, KKD Lima, JL Costa. 2015. Micropropagation of Eucalyptus saligna Sm. from cotyledonary nodes. Pakistan Journal of Botany 47(1): 311-318. https://www. pakbs.org/pjbot/PDFs/47(1)/44.pdf

Silva ALL, P Kielse, MA Horbach, GE Brondani, JM Walter, LF Santos, P Habibi, JF Araújo. 2019. Applications of micropropagation in plant biotechnology. In Stefenon VM ed. Micropropagation: methods and effects. New York, Nova Science Publishers. 1-24 p. https://novapublishers.com/ shop/micropropagation-methods-and-effects/

Souza DMSC, SB Fernandes, MLM Avelar, SRP Frade, LV Molinari, DS Gonçalves, GE Brondani. 2019. Mixotrophism effect on in vitro elongation and adventitious rooting of Eucalyptus dunnii. Cerne 25(4): 394-401. DOI: $\underline{10.1590 / 01047760201925042638}$

Wendling I, PR Brooks, SJ Trueman. 2015. Topophysis in Corymbia torelliana $\times$ C. citriodora seedlings: adventitious rooting capacity, stem anatomy, and auxin and abscisic acid concentrations. New Forests 46(1): 107-120. DOI: 10.1007/s11056-014-9451-7 